\title{
Synthesis of 3-Deoxy Analogs of Sphingolipids ${ }^{\dagger}$
}

\author{
Takeshi Kinsho and Kenji MORI* \\ Department of Agricultural Chemistry. The University of Tokyo, \\ 1-1-1 Yayoi, Bunkyo-ku, Tokyo 113, Japan
}

Received May 15, 1989

\begin{abstract}
To clarify the role of hydroxyl group at C-3 position in sphingolipid, 3-deoxy analogs of sphingolipids were synthesized employing enzymatic resolution of $\alpha$-amino acid as the key step.
\end{abstract}

All naturally occurring long-chain bases in sphingolipids that have ever been discovered have hydroxyl groups at the $\mathrm{C}-1$ and $\mathrm{C}-3$ positions. ${ }^{1)}$ The role of the primary hydroxyl group at $\mathrm{C}-1$ is to form the glycosyl bond with sugars in glycosphingolipids. The meaning of the secondary hydroxyl group, however, remains unclear. In the case of glycosphingolipids, there may be some interaction between the $\mathrm{C}-3$ hydroxyl group and the sugar moiety to influence the conformation of the molecule. From this point of view, it would be useful to investigate the properties of sphingolipids without the C-3 hydroxyl group, and their biological effects against various biosystems. Here are described a synthesis of optically active 3 -deoxysphingosine $\mathbf{1}$, and its conver-

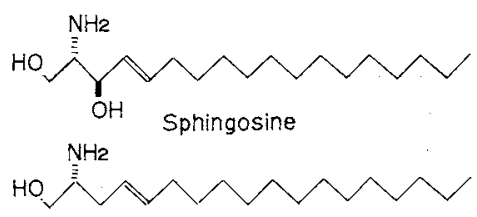

1 3-Deoxysphingosine
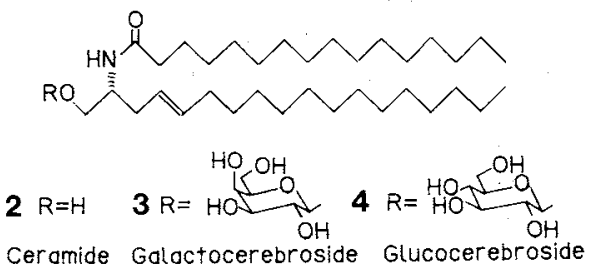

sion to deoxyceramide 2 , and deoxycerebrosides 3 and 4 .

The synthesis of 1 was achieved by employing the enzymatic resolution of $( \pm)$ - $N$-acetyl$\alpha$-amino acid $\mathbf{1 1}$ with amino acylase as the key step. The starting material for our synthesis was propargyl alcohol tetrahydropyranyl ether 5. The lithium salt of $\mathbf{5}$ was alkylated with tridecyl bromide to $\mathbf{6}$, which was deprotected to give alkynol 6' (93\% from 5). Reduction of $6^{\prime}$ with lithium aluminum hydride afforded $(E)$-alkenol 7, whose tretment with triphenylphosphine in carbon tetrachloride gave allylic chloride $\mathbf{8}$ in quantitative yield (2 steps). Alkylation of the anion prepared from diethyl acetaminomalonate with 8 yielded 9 in $95 \%$ yield. Decarboethoxylation by the method reported by Krapcho et al. ${ }^{2)}$ gave $\alpha$-acetamino ester 10. This was hydrolyzed by an alkaline treatment to give $( \pm)$-11. Asymmetric hydrolysis of ( \pm )-11 with Aspergillus amino acylase $^{3)}$ effectively gave $(S)-12$ as a precipitate and unhydrolyzed $(R)-11$ in the solution. These were readily separable by filtration.

$(R)-11$ was then esterified to methyl ester 13 according to Rachele. ${ }^{4)}$ This was reduced with lithium borohydride-methanol ${ }^{5}$ to give atcohol 14, whose deacetylation afforded the desired amino alcohol $\mathbf{1}$ (deoxysphingosine) in $69 \%$ yield from $(R)-11$.

Enantiomer $(S)-1$ was also synthesized by a

$\uparrow$ Synthesis of Sphingosine Relatives. Part VIII. For Part VII, see K. Mori and T. Kinsho, Liebigs Ann. Chem., 1988, 807. 1988 .

* Address correspondence to this author. 

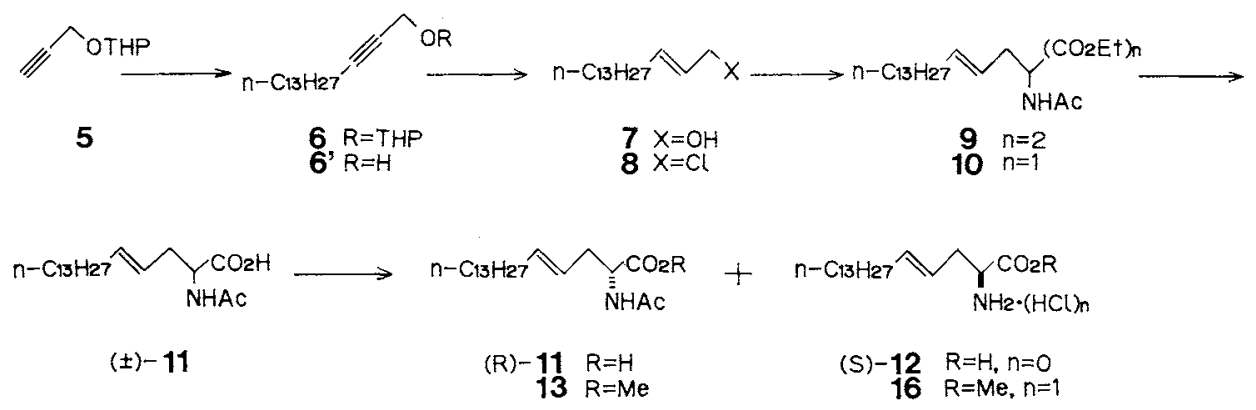

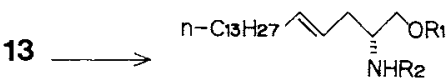

$\begin{array}{ll}14 & \mathrm{R}_{1}=\mathrm{H}_{1}, \mathrm{R}_{2}=\mathrm{AC} \\ \text { (R) }-1 & \mathrm{R}_{1}=\mathrm{R}_{2}=\mathrm{H}\end{array}$

$15 \quad R_{1}=R_{2}=(S)-M T P A$

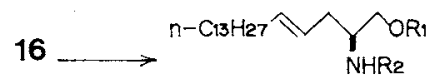

(S) $-1 \quad \mathrm{R}_{1}=\mathrm{R}_{2}=\mathrm{H}$

$17 R_{1}=R_{2}=(S)-M T P A$

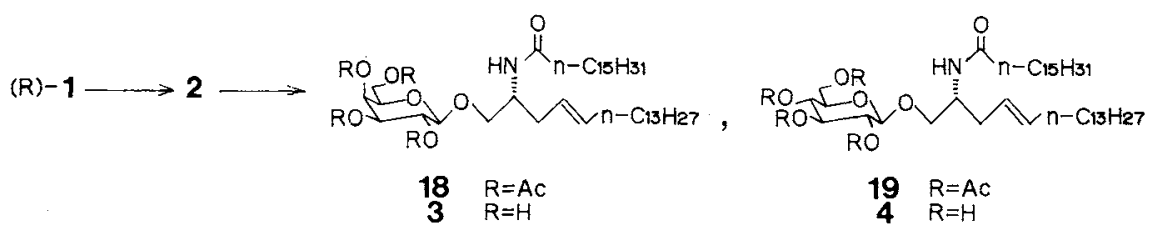

lithium aluminum hydride reduction of methyl ester hydrochloride 16 obtained from $(S)$-14. The optical purities of both enantiomers $(R)$ and $(S)$-1 were estimated by an HPLC analysis of their corresponding bis-( $S$ )-MTPA derivatives 15 and 17 , and revealed to be almost $100 \%$ e.e.

Deoxysphingosine $(R)-1$ was selectively $N$ acylated by treating with $p$-nitrophenyl palmitate in pyridine to give deoxyceramide $\mathbf{2}$ in $90 \%$ yield. Glycosylation of 2 with tetra$O$-acetylgalactopyranosyl bromide under Königs-Knorr conditions ${ }^{6)}$ and subsequent deacetylation gave the desired deoxygalactocerebroside $\mathbf{3}(80 \%$ from $\mathbf{2})$. Glucoside $\mathbf{4}$ was also synthesized in the same manner, using tetra- $O$ acetylglucopyranosyl bromide.

Biological studies employing these synthetic materials are underway by Prof. Y. Nagai in the Faculty of Medicine, the University of Tokyo.

\section{Experimental}

All bps and mps were uncorrected. IR spectra were measured as films for oils, and as $\mathrm{KBr}$ discs for solids, on a Jasco A-102 spectrophotometer. ${ }^{1} \mathrm{H}-\mathrm{NMR}$ spectra were recorded with the TMS as internal standard at $100 \mathrm{MHz}$ on a JEOL JNM FX-100, or at $400 \mathrm{MHz}$ on a JEOL JNM GX-400. ${ }^{13} \mathrm{C}-\mathrm{NMR}$ spectra were recorded with the TMS as internal standard at $100 \mathrm{MHz}$ on a JEOL JNM GX400. Optical rotations were measured on a JASCO DIP140 polarimeter.

2-Hexadecyn-1-ol (6'). A solution of $n$-butyllithium in $n$ hexane $(1.54 \mathrm{M}, 130 \mathrm{ml}, 200 \mathrm{mmol})$ was added dropwise to a solution of propargyl alcohol tetrahydropyranyl ether $(5,25.2 \mathrm{~g}, 180 \mathrm{mmol})$ in tetrahydrofuran $(250 \mathrm{ml})$ with stirring at $-20^{\circ} \mathrm{C}$ under argon. After stirring for $2 \mathrm{hr}$ at $-20^{\circ} \mathrm{C}$, a solution of 1-bromotridecane $(51.5 \mathrm{~g}, 196 \mathrm{mmol})$ in hexamethylphosphoric triamide $(100 \mathrm{ml})$ was added to the mixture. Stirring was continued for $2 \mathrm{hr}$ at $-20^{\circ} \mathrm{C}$ and for another $1 \mathrm{hr}$ at room temperature. The mixture was then poured into ice-cooled water and extracted with ether. The ether solution was washed with water and brine, dried with magnesium sulfate and concentrated in vacuo to give $59.3 \mathrm{~g}$ (quantitative) of 6 . This was dissolved in methanol $1000 \mathrm{ml}$ ), and $p$-toluenesulfonic acid monohydrate $(500 \mathrm{mg})$ was added to the solution. The mixture was stirred for $18 \mathrm{hr}$ at room temperature, before being poured into ice-cooled water and extracted with ether. The ether solution was washed with saturated sodium hydrogen carbonate solution and brine, dried with magnesium sulfate, and concentrated in vacuo. The residual solid was recrystallized from $n$-hexane to give $39.7 \mathrm{~g}(93 \%)$ of 6 , mp $49.5 \sim 50.0^{\circ} \mathrm{C}$; IR $v_{\max } \mathrm{cm}^{-1} 3320(\mathrm{~s}), 3200(\mathrm{~s}), 2220(\mathrm{w})$, $1470(\mathrm{~s}), 1025$ (s), $715(\mathrm{~s}) ; \mathrm{NMR} \delta_{\mathrm{H}}\left(100 \mathrm{MHz}, \mathrm{CDCl}_{3}\right)$ $0.88(3 \mathrm{H}, \mathrm{t}, J=6.0 \mathrm{~Hz}), 1.27(20 \mathrm{H}$, br. s $), 1.35 \sim 1.60(3 \mathrm{H}$, 
$\mathrm{m}), 2.08 \sim 2.32(2 \mathrm{H}, \mathrm{m}), 4.26(2 \mathrm{H}, \mathrm{t}, J=2.0 \mathrm{~Hz})$; GLC (column, $5 \% \mathrm{PEG}, 2 \mathrm{~m} \times 4 \mathrm{~mm}$ at $220^{\circ} \mathrm{C}$ : carrier gas, nitrogen, $\left.1.2 \mathrm{~kg} / \mathrm{cm}^{2}\right): t_{R}=9.41 \mathrm{~min}(99.6 \%)$. Anal. Found: C, 80.72 ; $\mathrm{H}, 12.59$. Calcd. for $\mathrm{C}_{16} \mathrm{H}_{30} \mathrm{O}: \mathrm{C}, 80.60 ; \mathrm{H}, 12.68 \%$.

(E)-2-Hexadecen-1-ol (7). A solution of $6^{\prime}(37.0 \mathrm{~g}, 155$ $\mathrm{mmol})$ in tetrahydrofuran $(500 \mathrm{ml})$ was added dropwise to an ice-cooled suspension of lithium aluminum hydride $(22.0 \mathrm{~g}, 580 \mathrm{mmol})$ in tetrahydrofuran $(300 \mathrm{ml})$. The mixture was stirred for $20 \mathrm{hr}$ at room temperature. With icecooling and vigorous stirring, ice-cooled water $(22 \mathrm{ml})$, a $15 \%$ aqueous solution of sodium hydroxide $(22 \mathrm{ml})$ and more ice-cooled water $(66 \mathrm{ml})$ were added in succession. After stirring for $30 \mathrm{~min}$ at room temperature, the precipitate was filtered off, and the filtrate was concentrated in vacuo. The residual solid was recrystallized from $n$-hexane to give $37.3 \mathrm{~g}$ (quantitative) of 7 as plates, $\mathrm{mp} 30.0 \sim$ $31.0^{\circ} \mathrm{C}$; IR $v_{\max } \mathrm{cm}^{-1} 3330(\mathrm{~s}), 1460(\mathrm{~s}), 1085(\mathrm{~s}), 1005(\mathrm{~s})$, $965(\mathrm{~s}), 710(\mathrm{~s}) ; \mathrm{NMR} \delta_{\mathrm{H}}\left(100 \mathrm{MHz}, \mathrm{CDCl}_{3}\right) 0.88(3 \mathrm{H}, \mathrm{t}$, $J=6.0 \mathrm{~Hz}), 1.27(22 \mathrm{H}$, br. s), $1.53(1 \mathrm{H}, \mathrm{s}), 2.03(2 \mathrm{H}, \mathrm{m})$, $4.06(2 \mathrm{H}, \mathrm{m}), 5.66(2 \mathrm{H}, \mathrm{m})$; GLC (column, 5\% PEG, $2 \mathrm{~m} \times 4 \mathrm{~mm}$ at $220^{\circ} \mathrm{C}$; carrier gas, nitrogen, $\left.1.1 \mathrm{~kg} / \mathrm{cm}^{2}\right)$ : $t_{\mathbf{R}}=5.81 \mathrm{~min}(98.8 \%)$. Anal. Found: C, 79.64; H, 13.10 . Calcd. for $\mathrm{C}_{16} \mathrm{H}_{32} \mathrm{O}$ : C, $79.93 ; \mathrm{H}, 13.42 \%$.

(E)-1-Chloro-2-hexadecene (8). A mixture of 7 (4.09g, $17.0 \mathrm{mmol})$ and triphenylphosphine $(6.10 \mathrm{~g}, 25.6 \mathrm{mmol})$ in carbon tetrachloride $(20 \mathrm{ml})$ was stirred for $13 \mathrm{hr}$ under reflux. After cooling, the mixture was filtered through silica gel $(75 \mathrm{~g})$ and eluted with carbon tetrachloride to remove the triphenylphosphine oxide. The filtrate was concentrated in vacuo and the residue was chromatographed over silica gel $(75 \mathrm{~g})$. Elution with $n$-hexane gave $4.40 \mathrm{~g}$ (quantitative) of 8 as an oil, $n_{\mathrm{D}}^{21}=1.4544$; IR $v_{\max }$ $\mathrm{cm}^{-1} 1665(\mathrm{~m}), 1460(\mathrm{~s}), 1440(\mathrm{~s}), 1250(\mathrm{~s}), 965(\mathrm{~s}), 720(\mathrm{~m})$, $680(\mathrm{~s}) ; \mathrm{NMR} \delta_{\mathrm{H}}\left(100 \mathrm{MHz}, \mathrm{CDCl}_{3}\right) 0.88(3 \mathrm{H}, \mathrm{t}, J=$ $6.0 \mathrm{~Hz}), 1.27(22 \mathrm{H}$, br. s) $2.06(2 \mathrm{H}, \mathrm{m}), 4.05(2 \mathrm{H}, \mathrm{d}, J=$ $6.2 \mathrm{~Hz}), 5.56(1 \mathrm{H}, \mathrm{dt}, J=15.0,6.2 \mathrm{~Hz}), 5.80(1 \mathrm{H}, \mathrm{dt}, J=$ 15.0, 6.0 Hz). Anal. Found: C, 73.89; H, 11.80. Calcd. for $\mathrm{C}_{16} \mathrm{H}_{31} \mathrm{Cl}: \mathrm{C}, 74.23 ; \mathrm{H}, 12.07 \%$.

Diethyl (E)-2-acetamino-2-(2'-hexadecenyl)malonate (9). Diethyl acetaminomalonate $(24.4 \mathrm{~g}, 112 \mathrm{mmol})$ in absolute ethanol $(400 \mathrm{ml})$ was added to a solution of sodium ethoxide [prepared from sodium metal $(2.48 \mathrm{~g}$, $108 \mathrm{mg}$ atom)] in absolute ethanol $(130 \mathrm{ml})$. After stirring for $30 \mathrm{~min}$ at room temperature, $8(22.3 \mathrm{~g}, 86.1 \mathrm{mmol}$ was added to the mixture. The mixture was stirred for $4 \mathrm{hr}$ under reflux and then for $18 \mathrm{hr}$ at room temperature, before the solvent was removed in vacuo. The residue was diluted with ice-cooled water and extracted with ether. The ether solution was washed with brine and concentrated in vacuo. The residual solid was recrystallized from ethyl acetate- $n$-hexane $(1: 1)$ to give $36.1 \mathrm{~g}(95 \%)$ of 9 as granules, mp $55.5 \sim 56.0^{\circ} \mathrm{C}$; IR $v_{\max } \mathrm{cm}^{-1} 3250(\mathrm{~s}), 1750$ (s), $1735(\mathrm{~s}), 1645(\mathrm{~s}), 1530(\mathrm{~s}), 1300(\mathrm{~s}), 1225(\mathrm{~s}), 970(\mathrm{~m})$; NMR $\delta_{\mathrm{H}}\left(100 \mathrm{MHz}, \mathrm{CDCl}_{3}\right) 0.88(3 \mathrm{H}, \mathrm{t}, J=6.0 \mathrm{~Hz}), 1.24$
$(22 \mathrm{H}$, br. $\mathrm{s}), 1.26(6 \mathrm{H}, \mathrm{t}, J=7.0 \mathrm{~Hz}), 1.80 \sim 2.06(2 \mathrm{H}, \mathrm{m})$, $2.04(3 \mathrm{H}, \mathrm{s}), 3.00(2 \mathrm{H}, \mathrm{d}, J=7.2 \mathrm{~Hz}), 4.25(4 \mathrm{H}, \mathrm{q}, J=$ $7.0 \mathrm{~Hz}), 5.12(1 \mathrm{H}, \mathrm{dt}, J=15.0,7.5 \mathrm{~Hz}), 5.52(1 \mathrm{H}, \mathrm{dt}, J=$ $15.0,7.0 \mathrm{~Hz}), 6.63(1 \mathrm{H}, \mathrm{br}$.$) . Anal. Found: C, 68.49; \mathrm{H}$, $10.25 ; \mathrm{N}, 3.14$. Calcd. for $\mathrm{C}_{25} \mathrm{H}_{45} \mathrm{O}_{5} \mathrm{~N}: \mathrm{C}, 68.30 ; \mathrm{H}, 10.32$; $\mathrm{N}, 3.19 \%$.

Ethyl (E)-2-acetamino-4-octadecenoate (10). A mixture of $9(37.3 \mathrm{~g}, 84.8 \mathrm{mmol})$ and sodium chloride $(5.28 \mathrm{~g}, 90.3$ $\mathrm{mmol})$ in dimethyl sulfoxide $(190 \mathrm{ml})$ and water $(3.10 \mathrm{ml})$ was stirred under reflux for $18 \mathrm{hr}$. It was then poured into ice-cooled water and extracted with ethyl acetate. The ethyl acetate solution was washed with brine, dried with magnesium sulfate, and concentrated in vacuo. The residue was chromatographed over silica gel $(200 \mathrm{~g})$. Elution with $n$-hexane-ethyl acetate $(3: 1)$ gave $25.7 \mathrm{~g}(82 \%)$ of 10 as needles, mp $53.0 \sim 54.0^{\circ} \mathrm{C}$; IR $v_{\max } \mathrm{cm}^{-1} 3250(\mathrm{~s}), 1745(\mathrm{~s})$, $1635(\mathrm{~s}), 1550(\mathrm{~s}), 1470(\mathrm{~s}), 1375(\mathrm{~s}), 1195(\mathrm{~s}), 965(\mathrm{~s}), 720$ $(\mathrm{m}) ; \mathrm{NMR} \delta_{\mathrm{H}}\left(100 \mathrm{MHz}, \mathrm{CDCl}_{3}\right) 0.88(3 \mathrm{H}, \mathrm{t}, J=6.0 \mathrm{~Hz})$, $1.24(22 \mathrm{H}$, br. s), $1.26(3 \mathrm{H}, \mathrm{t}, J=7.5 \mathrm{~Hz}), 1.73 \sim 2.20(2 \mathrm{H}$, $\mathrm{m}), 2.01(3 \mathrm{H}, \mathrm{s}), 2.50(2 \mathrm{H}, \mathrm{t}, J=6.0 \mathrm{~Hz}), 4.20(2 \mathrm{H}, \mathrm{q}, J=$ $7.1 \mathrm{~Hz}), 4.62(1 \mathrm{H}, \mathrm{dt}, J=7.8,5.7 \mathrm{~Hz}), 5.24(1 \mathrm{H}, \mathrm{dt}, J=$ $15.2,6.7 \mathrm{~Hz}), 5.53(1 \mathrm{H}, \mathrm{dt}, J=15.2,6.0 \mathrm{~Hz}), 6.00(1 \mathrm{H}, \mathrm{d}$, $J=7.8 \mathrm{~Hz}$ ). Anal. Found: C, 72.35; H, 11.26; N, 4.21 . Calcd. for $\mathrm{C}_{22} \mathrm{H}_{41} \mathrm{O}_{3} \mathrm{~N}$ : C, 71.88; $\mathrm{H}, 11.24 ; \mathrm{N}, 3.81 \%$.

(E)-Acetamino-4-octadecenoic acid (( \pm$)$-11). A solution of potassium hydroxide $(5.64 \mathrm{~g}, 101 \mathrm{mmol})$ in water $(100 \mathrm{ml})$ was added to a solution of $10(23.5 \mathrm{~g}, 63.9 \mathrm{mmol})$ in tetrahydrofuran $(200 \mathrm{ml})$. The mixture was stirred and heated under reflux for $5 \mathrm{hr}$, before solvent was removed in vacuo. The residue was diluted with ice-cooled water $(100 \mathrm{ml})$, acidified by adding $2 \mathrm{~N}$ hydrochloric acid to $\mathrm{pH} 4$, and extracted with ether. The ether solution was washed with water, dried with magnesium sulfate, and concentrated in vacuo. The residual solid was recrystallized from ethyl acetate- $n$-hexane $(2: 1)$ to give $18.8 \mathrm{~g}(87 \%)$ of $( \pm)$ 11 as plates, $\mathrm{mp} 108 \sim 109^{\circ} \mathrm{C}$; IR $v_{\max } \mathrm{cm}^{-1} 3300$ (vs), $2600 \sim 2200$ (br.), 1710 (s), 1580 (vs), 1530 (vs), 1450 (m), $1420(\mathrm{~m}), 1365(\mathrm{~s}), 1330(\mathrm{~m}), 1210(\mathrm{~m}), 950(\mathrm{~m}), 705(\mathrm{~m})$; NMR $\delta_{\mathrm{H}}\left(100 \mathrm{MHz}, \mathrm{CDCl}_{3}\right) 0.88(3 \mathrm{H}, \mathrm{t}, J=6.0 \mathrm{~Hz}), 1.24$ ( $22 \mathrm{H}$, br. s), $1.90 \sim 2.14(2 \mathrm{H}, \mathrm{m}), 2.07(3 \mathrm{H}, \mathrm{s}), 2.54(2 \mathrm{H}, \mathrm{t}$, $J=6.0 \mathrm{~Hz}), 3.85\left(1 \mathrm{H}\right.$, br., disappeared by $\mathrm{D}_{2} \mathrm{O}$ replacement $), 4.60(1 \mathrm{H}, \mathrm{dt}, J=8.0,6.0 \mathrm{~Hz}), 5.30(1 \mathrm{H}, \mathrm{dt}, J=16.0$, $6.5 \mathrm{~Hz}), 5.49(\mathrm{lH}, \mathrm{dt}, J=16.0,6.0 \mathrm{~Hz}), 5.99(1 \mathrm{H}, \mathrm{d}, J=$ $8.0 \mathrm{~Hz}$ ). Anal. Found: C, 70.70; H, 10.82; N, 4.06. Calcd. for $\mathrm{C}_{20} \mathrm{H}_{37} \mathrm{O}_{3} \mathrm{~N}: \mathrm{C}, 70.75 ; \mathrm{H}, 10.99 ; \mathrm{N}, 4.13 \%$.

(2R,4E)-2-Acetamino-4-octadecenoic acid $((R)-11)$ and (2S,4E)-2-amino-4-octadecenoic acid $((S)$-12) by enzymatic resolution of $( \pm)-11$ with amino acylase. Amino acylase (from Aspergillus, 10,000 units/g, Tokyo Kasei Co., 3.8 g) and cobaltous chloride ( $c a .10 \mathrm{mg}$ ) were added to a solution of $( \pm)-11(18.7 \mathrm{~g}, 55.1 \mathrm{mmol})$ in water $(3100 \mathrm{ml})$ that was adjusted to $\mathrm{pH} 7.1$ by adding sodium hydroxide. The solution was left to stand for 2 days at $37^{\circ} \mathrm{C}$. The resulting turbid mixture was then acidified by the addition 
of $2 \mathrm{~N}$ hydrochloric acid to $\mathrm{pH} 3$. The precipitated solid was collected on a filter, and washed with hot ethyl acetate $(300 \mathrm{ml} \times 4)$. The insoluble precpitate was washed with water, methanol and ether, and dried over phosphorous pentoxide to give $8.20 \mathrm{~g}$ (quantitative) of crude $(S)-12$ as an amorphous solid, $\mathrm{mp} 177 \sim 182^{\circ} \mathrm{C}$ (decomposition point); IR $v_{\max } \mathrm{cm}^{-1} 3300$ (br.), 1580 (s), $1500(\mathrm{~m}), 1465$ (m), $1415(\mathrm{~m}), 1400(\mathrm{~s}), 1140(\mathrm{~m}), 965(\mathrm{~s}), 720(\mathrm{~m})$. This material was employed in the next step without further purification.

The ethyl acetate solution was dried with magnesium sulfate and concentrated in vacuo. The residual solid was recrystallized from ethyl acetate- $n$-hexane $(1: 5)$ to give $6.06 \mathrm{~g}(65 \%)$ of $(R)-11$ as fine needles, $\mathrm{mp} 104 \sim 105^{\circ} \mathrm{C}$; $[\alpha]_{\mathrm{D}}^{23}-45.0^{\circ}\left(c=0.50, \mathrm{CHCl}_{3}\right)$; IR $v_{\max } \mathrm{cm}^{-1} 3360(\mathrm{~s}), 2600$ (m), $2460(\mathrm{~m}), 1710(\mathrm{~s}), 1630(\mathrm{~s}), 1555(\mathrm{~s}), 1470(\mathrm{~s}), 1270$ $(\mathrm{s}), 1240(\mathrm{~s}), 965(\mathrm{~s}), 720(\mathrm{~m}) ; \mathrm{NMR} \delta_{\mathrm{H}}\left(100 \mathrm{MHz}, \mathrm{CDCl}_{3}\right)$ $0.88(3 \mathrm{H}, \mathrm{t}, J=6.0 \mathrm{~Hz}), 1.27(22 \mathrm{H}$, br. $\mathrm{s}), 1.78 \sim 2.10(2 \mathrm{H}$, m), $2.06(3 \mathrm{H}, \mathrm{s}), 2.54(2 \mathrm{H}$, br. t, $J=6.0 \mathrm{~Hz}), 3.07(\mathrm{lH}$, br., disappeared by $\mathrm{D}_{2} \mathrm{O}$ replacement), $4.58(1 \mathrm{H}, \mathrm{dt}, J=7.2$, $6.1 \mathrm{~Hz}), 5.29(1 \mathrm{H}, \mathrm{dt}, J=15.0,6.2 \mathrm{~Hz}), 5.60(1 \mathrm{H}, \mathrm{dt}, J=$ $15.0,6.0 \mathrm{~Hz}), 5.96(1 \mathrm{H}, \mathrm{d}, J=7.2 \mathrm{~Hz})$. Anal. Found: C, 71.04; $\mathrm{H}, 10.95 ; \mathrm{N}, 4.13$. Calcd. for $\mathrm{C}_{20} \mathrm{H}_{37} \mathrm{O}_{3} \mathrm{~N}$ : C, 70.75; $\mathrm{H}, 10.99 ; \mathrm{N}, 4.13 \%$.

Methyl (2R,4E)-2-acetamino-4-octadecenoate $((R)$-13) To a solution of $(R)-11(3.00 \mathrm{~g}, 8.84 \mathrm{mmol})$ in $2,2-$ dimethoxypropane $(100 \mathrm{ml})$ was added concentrated hydrochloric acid $(8.84 \mathrm{ml})$. The mixture was stirred for $18 \mathrm{hr}$ at room temperature, before the solvent was removed in vacuo, and the residue was chromatographed over silica gel $(60 \mathrm{~g})$. Elution with $n$-hexane-ether $(1: 2)$ gave crude (R)-13, which was recrystallized from $n$-hexane to give $2.85 \mathrm{~g}(96 \%)$ of $(R)-13$ as fine needles, $\mathrm{mp} 69.0 \sim 70.5^{\circ} \mathrm{C}$; $[\alpha]_{\mathrm{D}}^{17}-41.6\left(c=0.60, \mathrm{CHCl}_{3}\right) ; \mathrm{IR} v_{\max } \mathrm{cm}^{-1} 3280(\mathrm{~s}), 1730$ (s), $1660(\mathrm{~s}), 1550(\mathrm{~s}), 1460(\mathrm{~m}), 1430(\mathrm{~m}), 1375(\mathrm{~m}), 1300$ $(\mathrm{m}), 965(\mathrm{~m}) ; \mathrm{NMR} \delta_{\mathrm{H}}\left(100 \mathrm{MHz}, \mathrm{CDCl}_{3}\right) 0.88(3 \mathrm{H}, \mathrm{t}, J=$ $6.4 \mathrm{~Hz}), 1.27(22 \mathrm{H}$, br. s), $1.85 \sim 2.04(2 \mathrm{H}, \mathrm{m}), 2.02(3 \mathrm{H}, \mathrm{s})$, $2.47(2 \mathrm{H}$, br. t, $J=6.2 \mathrm{~Hz}), 3.74(3 \mathrm{H}, \mathrm{s}), 4.63(1 \mathrm{H}, \mathrm{dt}, J=$ $8.0,6.0 \mathrm{~Hz}), 5.23(1 \mathrm{H}, \mathrm{dt}, J=15.0,6.9 \mathrm{~Hz}), 5.54(1 \mathrm{H}, \mathrm{dt}$, $J=15.0,6.2 \mathrm{~Hz}), 5.94(1 \mathrm{H}, \mathrm{d}, J=8.0 \mathrm{~Hz})$. Anal. Found: C, 71.26; H, 11.16; N, 4.01. Calcd. for $\mathrm{C}_{21} \mathrm{H}_{39} \mathrm{O}_{3} \mathrm{~N}$ : C, 71.34; $\mathrm{H}, 11.12 ; \mathrm{N}, 3.96 \%$.

$(2 R, 4 E)$-2-Acetamino-4-octadecen- $I$-ol $((R)$-14). A mixture of $(R)-13(2.85 \mathrm{~g}, 8.06 \mathrm{mmol})$ and lithium borohydride $(0.96 \mathrm{~g}, 44.1 \mathrm{mmol})$ in ether $(100 \mathrm{ml})$ was stirred and heated under reflux. To this was added methanol $(0.495 \mathrm{ml}, 8.11$ mmol) dropwise over $70 \mathrm{~min}$. After stirring for $30 \mathrm{~min}$ under reflux, the mixture was cooled in an ice bath, and the excess lithium borohydride was quenched by the addition of $2 \mathrm{~N}$ hydrochloric acid. The mixture was then diluted with ice-cooled water and extracted with chloroform. The chloroform solution was washed with brine, dried with magnesium sulfate and concentrated in vacuo. The residue was chromatographed over silica gel (75 g), and elution with ether gave crude $(R)-14$, which was recrystallized from $n$-hexane-ether $(5: 1)$ to give $1.87 \mathrm{~g}$ $(71 \%)$ of $(R)-14$ as an amorphous solid, mp $71.0 \sim 72.0^{\circ} \mathrm{C}$; $[\alpha]_{\mathrm{D}}^{17}-5.06^{\circ}\left(c=0.78, \mathrm{CHCl}_{3}\right) ; \mathrm{IR} v_{\max } \mathrm{cm}^{-1} 3310(\mathrm{~s}), 1650$ (s), $1555(\mathrm{~s}), 1465(\mathrm{~m}), 1425(\mathrm{~m}), 1370(\mathrm{~m}), 1035(\mathrm{~m}), 965$ (m), $720(\mathrm{~m}) ; \mathrm{NMR} \delta_{\mathrm{H}}\left(100 \mathrm{MHz}, \mathrm{CDCl}_{3}\right) 0.88(3 \mathrm{H}, \mathrm{t}, J=$ $6.0 \mathrm{~Hz}), 1.28(22 \mathrm{H}$, br. s), $1.97(2 \mathrm{H}, \mathrm{m}), 2.02(3 \mathrm{H}, \mathrm{s}), 2.24$ ( $2 \mathrm{H}$, br. t, $J=7.0 \mathrm{~Hz}), 2.88(1 \mathrm{H}$, br. $), 3.50 \sim 3.67(1 \mathrm{H}, \mathrm{m})$, $3.67 \sim 4.28(2 \mathrm{H}, \mathrm{m}), 5.34(1 \mathrm{H}, \mathrm{dt}, J=15.2,6.2 \mathrm{~Hz}), 5.56$ $(1 \mathrm{H}, \mathrm{dt}, J=15.2,6.4 \mathrm{~Hz}), 5.88(1 \mathrm{H}, \mathrm{d}, J=7.0 \mathrm{~Hz})$. Anal. Found: $\mathrm{C}, 73.27 ; \mathrm{H}, 11.75 ; \mathrm{N}, 4.24$. Calcd. for $\mathrm{C}_{20} \mathrm{H}_{39} \mathrm{O}_{2} \mathrm{~N}: \mathrm{C}, 73.79 ; \mathrm{H}, 12.08 ; \mathrm{N}, 4.30 \%$.

(E)-2-Amino-4-octadecen-1-ol ((R)-1). A mixture of $(R)$ $14(1.30 \mathrm{~g}, 4.00 \mathrm{mmol})$ and $2 \mathrm{~N}$ hydrochloric acid was stirred for $30 \mathrm{~min}$ under reflux. It was then diluted with icecooled water, neutralized with $2 \mathrm{~N}$ ammonia water to $\mathrm{pH} 8$, and extracted with methylene chloride. The methylene chloride solution was washed with brine and concentrated in vacuo. The residue was chromatographed over silica gel $(20 \mathrm{~g})$, and elution with chloroform-methanol $(9: 1)$ gave $1.13 \mathrm{~g}$ (quantitative) of crude $(R)-1$. This material was employed in the next step without further purification.

For use in the bioassay and analysis, a part of this material was further purified by adding an ion-exchange resin (Amberlyst IRA-400 OH ${ }^{-}$form, $40.5 \mathrm{ml}, 56.7 \mathrm{mmol}$ ) to a solution of crude $(R)-1(126 \mathrm{mg}, 0.390 \mathrm{mmol})$ in $99 \%$ ethanol $(600 \mathrm{ml})$. After stirring for $1 \mathrm{hr}$, the resin was removed by filtration and the filtrate was concentrated in vacuo. The residue was chromatographed over neutral alumina (grade IV $20 \mathrm{~g}$ ), and elution with $99 \%$ ethanol gave $88 \mathrm{mg}$ of $(R)-1$ as an amorphous solid, $\mathrm{mp}$ $56.0 \sim 57.5^{\circ} \mathrm{C}$; IR $v_{\max } \mathrm{cm}^{-1} 3440(\mathrm{~s}), 1600(\mathrm{~m}), 1570(\mathrm{~m})$, $1465(\mathrm{~s}), 1015(\mathrm{~m}), 970(\mathrm{~s}), 720(\mathrm{~m})$; NMR $\delta_{\mathrm{H}}(100 \mathrm{MHz}$, $\left.\mathrm{CDCl}_{3}\right) 0.88(3 \mathrm{H}, \quad \mathrm{t}, \quad J=6.0 \mathrm{~Hz}), 1.27 \quad(22 \mathrm{H}, \quad$ br. $\mathrm{s})$, $1.60 \sim 2.30\left(7 \mathrm{H}, \mathrm{m}\right.$, the integral value decreased by $\mathrm{D}_{2} \mathrm{O}$ replacement), $2.70 \sim 3.72(3 \mathrm{H}, \mathrm{m}), 5.32(1 \mathrm{H}, \mathrm{dt}, J=16.0$, $5.9 \mathrm{~Hz}), 5.54(1 \mathrm{H}, \mathrm{dt}, J=16.0,5.9 \mathrm{~Hz})$.

The optical purity of $(R)-1$ was estimated by an HPLC analysis of the corresponding bis[( $S)$-MTPA] derivative $\mathbf{1 5}$ (column, Senshu Pak silica-125l-N, $25 \mathrm{~cm} \times 4.6 \mathrm{~mm}$; solvent, $n$-hexane-tetrahydrofuran $=15: 1$; flow rate, $1.0 \mathrm{ml}$ / min) $t_{R}=14.4 \mathrm{~min}(100 \%)$. The peak due to 17 at $t_{R}=$ $13.3 \mathrm{~min}$ was not detected; therefore, our $(R)-1$ was of almost $100 \%$ e.e.

Methyl (2S,4E)-2-amino-4-octadecenoate hydrochloride (16). A mixture of $(S)-12(4.00 \mathrm{~g}, 13.4 \mathrm{mmol})$ and concentrated hydrochloric acid $(13.4 \mathrm{ml}, 162 \mathrm{mmol})$ in 2,2 dimethoxypropane-methanol $(5: 1,84 \mathrm{ml})$ was stirred for $15 \mathrm{~min}$ under reflux at $70^{\circ} \mathrm{C}$ and for $12 \mathrm{hr}$ at room temperature. The solvent was then removed in vacuo and the residual solid was recrystallized from methanol-ether $(1: 1)$ to give $3.23 \mathrm{~g}(69 \%)$ of 16 as fine needles, $\mathrm{mp}$ $112 \sim 113^{\circ} \mathrm{C}$; IR $v_{\max } \mathrm{cm}^{-\mathrm{i}} 1745(\mathrm{~s}), 1595(\mathrm{w}), 1500(\mathrm{~s})$, $1465(\mathrm{~s}), 1245(\mathrm{~s}), 975(\mathrm{~s}), 720(\mathrm{~m})$; NMR $\delta_{\mathrm{H}}(100 \mathrm{MHz}$, $\left.\mathrm{CDCl}_{3}\right) 0.88(3 \mathrm{H}, \mathrm{t}, J=6.2 \mathrm{~Hz}), 1.27(22 \mathrm{H}$, br. s) $2.30(2 \mathrm{H}$, $\mathrm{m}), 2.76(2 \mathrm{H}, \mathrm{m}), 3.81(3 \mathrm{H}, \mathrm{s}), 3.85 \sim 4.25(3 \mathrm{H}$, br., the 
integral value decreased by $\mathrm{D}_{2} \mathrm{O}$ replacement $), 5.43(1 \mathrm{H}$, $\mathrm{m}), 5.70(1 \mathrm{H}, \mathrm{m})$. Anal. The hydrochloride content varied from 1.2 to 1.6. Found: C, 63.32; H, 10.66; N, 4.16. Calcd. for $\mathrm{C}_{19} \mathrm{H}_{37} \mathrm{O}_{2} \mathrm{~N} \cdot 1.34 \mathrm{HCl}: \mathrm{C}, 63.33 ; \mathrm{H}, 10.72 ; \mathrm{N}, 3.89 \%$. Found: $\mathrm{C}, 61.91 ; \mathrm{H}, 10.47 ; \mathrm{N}, 3.89$. Caled. for $\mathrm{C}_{19} \mathrm{H}_{37} \mathrm{O}_{2} \mathrm{~N} \cdot 1.57 \mathrm{HCl}: \mathrm{C}, 61.89 ; \mathrm{H}, 10.54 ; \mathrm{N}, 3.80 \%$. This material was employed in the next step without further purification.

For analytical use, the free amine of $\mathbf{1 6}$ was prepared from a mixture of hydrochloride $16(940 \mathrm{mg}, 2.70 \mathrm{mmol})$ and potassium carbonate $(400 \mathrm{mg}, 2.89 \mathrm{mmol})$ in methanol-tetrahydrofuran $(1: 1,30 \mathrm{ml})$, which was stirred for $24 \mathrm{hr}$ at room temperature. It was then diluted with ether and filtered through Celite to remove the salts. The filtrate was dried with magnesium sulfate and concentrated in vacuo. The oily residue was chromatographed over silica gel $(10 \mathrm{~g})$, and elution with $n$-hexane-ether $(1: 1)$ gave $740 \mathrm{mg}(88 \%)$ of the free amine as an oil, IR $v_{\mathrm{max}}$ $\mathrm{cm}^{-1} 3400(\mathrm{~m}), 1740(\mathrm{~s}), 1200(\mathrm{~s}), 1170(\mathrm{~s}), 965(\mathrm{~m}) ; \mathrm{NMR}$ $\delta_{\mathrm{H}}\left(100 \mathrm{MHz}, \mathrm{CDCl}_{3}\right) 0.88(3 \mathrm{H}, \mathrm{t}, J=6.2 \mathrm{~Hz}), 1.27(22 \mathrm{H}$, br. s), $1.70(2 \mathrm{H}$, br.s $), 1.95(2 \mathrm{H}, \mathrm{m}), 2.38(2 \mathrm{H}, \mathrm{m}), 3.53$ $(1 \mathrm{H}, \mathrm{t}, J=6.0 \mathrm{~Hz}), 3.74(3 \mathrm{H}, \mathrm{s}), 5.30(1 \mathrm{H}, \mathrm{dt}, J=15.0$, $6.0 \mathrm{~Hz}), 5.57(1 \mathrm{H}, \mathrm{dt}, J=15.0,6.0 \mathrm{~Hz})$. Anal. Found: C, 73.48; $\mathrm{H}, 11.51 ; \mathrm{N}, 4.41$. Calcd. for $\mathrm{C}_{19} \mathrm{H}_{37} \mathrm{O}_{2} \mathrm{~N}: \mathrm{C}, 73.26$; $\mathrm{H}, 11.97 ; \mathrm{N}, 4.50 \%$.

(2S,4E)-2-Amino-4-octadecen-1-ol ((S)-1). A solution of $16(200 \mathrm{mg}, 0.575 \mathrm{mmol})$ in tetrahydrofuran $(25 \mathrm{ml})$ was added dropwise to an ice-cooled suspension of lithium aluminum hydride $(120 \mathrm{mg}, 3.16 \mathrm{mmol})$ in tetrahydrofuran ( $1 \mathrm{ml}$ ). The mixture was stirred for $16 \mathrm{hr}$ at room temperature. With ice-cooling and vigorous stirring, water $(0.12 \mathrm{ml})$, a $15 \%$ aqueous solution of sodium hydroxide $(0.12 \mathrm{ml})$, and more water $(0.36 \mathrm{ml})$ were added in succession. After stirring for $30 \mathrm{~min}$ at room temperature, the precipitate was filtered off. The filtrate was dried with magnesium sulfate, and concentrated in vacuo. The residue was chromatographed over silica gel $(15 \mathrm{~g})$, and elution with chloroform-methanol $(9: 1)$ gave $130 \mathrm{mg}(80 \%)$ of $(S)-1$ as an amorphous solid, mp $55.5 \sim 59.0^{\circ} \mathrm{C}$. Its IR and NMR spectra were identical with those of $(R)-1$. The optical purity of $(S)$-1 was estimated in the same manner as that described for 15 by an HPLC analysis of the corresponding bis $[(S)$-MTPA $]$ derivative $17, t_{R}=13.3 \mathrm{~min}$ $(100 \%)$. The peak due to 15 at $t_{R}=14.4 \mathrm{~min}$ was not detected; therefore, our $(S)-1$ was of almost $100 \%$ e.e.

(2R,4E)-2-N-Hexadecanoylamino-4-octadecen-1-ol (2). A solution of crude $(R)-1(220 \mathrm{mg}, c a .770 \mathrm{mmol})$ and $p$ nitrophenyl hexadecanoate $(380 \mathrm{mg}, 1.01 \mathrm{mmol})$ in pyridine $(10 \mathrm{ml})$ was stirred for $2 \mathrm{hr}$ at $50^{\circ} \mathrm{C}$ and for $16 \mathrm{hr}$ at room temperature. The solvent was removed in vacuo, and the residue was chromatographed over silica gel $(25 \mathrm{~g})$. Elution with $n$-hexane-ether (2:1) gave crude 2, which was recrystallized from ether to give $365 \mathrm{mg}(90 \%)$ of 2 as cubes, $\mathrm{mp} 71.5 \sim 72.0^{\circ} \mathrm{C} ;[\alpha]_{\mathrm{D}}^{20}-3.62^{\circ}\left(c=0.57, \mathrm{CHCl}_{3}\right)$; IR $v_{\max } \mathrm{cm}^{-1} 3450(\mathrm{~s}), 3330(\mathrm{~s}), 3280(\mathrm{~s}), 1645(\mathrm{~s}), 1605(\mathrm{~s})$, $1550(\mathrm{~s}), 1465(\mathrm{~s}), 965(\mathrm{~s}), 720(\mathrm{~s}) ; \mathrm{NMR} \delta_{\mathrm{H}}(100 \mathrm{MHz}$, $\left.\mathrm{CDCl}_{3}\right) 0.88\left(6 \mathrm{H}, \mathrm{t}, J=6.0 \mathrm{~Hz}, 18-\mathrm{H}_{3}, 16^{\prime}-\mathrm{H}_{3}\right), 1.27(48 \mathrm{H}$, br.s), 1.57 (1H, br., OH), $1.85 \sim 2.32\left(6 \mathrm{H}, \mathrm{m}, 3-\mathrm{H}_{2}, 6-\mathrm{H}_{2}\right.$, $\left.2-\mathrm{H}_{2}\right), 3.40 \sim 4.06\left(3 \mathrm{H}, \mathrm{m}, 1-\mathrm{H}_{2}, 2-\mathrm{H}\right), 5.33(1 \mathrm{H}, \mathrm{dt}, J=$ $15.0,6.0 \mathrm{~Hz}, 5-\mathrm{H}), 5.54(1 \mathrm{H}, \mathrm{dt}, J=15.0,6.0 \mathrm{~Hz}, 4-\mathrm{H})$, $5.68(1 \mathrm{H}, \mathrm{d}, J=8.0 \mathrm{~Hz}, \mathrm{NH})$; FD-MS $m / z: 522(\mathrm{M}+\mathrm{H})^{+}$. Anal. Found: $\mathrm{C}, 78.20 ; \mathrm{H}, 12.58 ; \mathrm{N}, 2.66$. Calcd. for $\mathrm{C}_{34} \mathrm{H}_{67} \mathrm{O}_{2} \mathrm{~N}: \mathrm{C}, 78.26 ; \mathrm{H}, 12.92 ; \mathrm{N}, 2.68 \%$

$\left(2^{\prime} R, 4^{\prime} E\right)-1-O-\left(2^{\prime}-H e x a d e c a n o y l a m i n o-4^{\prime}\right.$-octadecenyl $)-$ $2,3,4,6$-tetra-O-acetyl- $\beta$-D-galactopyranoside (18). Dry benzene $(20 \mathrm{ml})$ was added to a solution of $2(600 \mathrm{mg}, 1.15$ $\mathrm{mmol})$ in nitromethane-acetonitrile $(7: 2,45 \mathrm{ml})$, and the solution was stirred and heated at $110^{\circ} \mathrm{C}$ to remove the moisture azeotropically with benzene. The mixture was concentrated to the volume of $\mathrm{ca} .30 \mathrm{ml}$, and cooled under argon. To the solution was added 2,3,4,6-tetra- $O$ acetylgalactopyranosy bromide $(710 \mathrm{mg}, 1.73 \mathrm{mmol})$ and mercuric cyanide $(434 \mathrm{mg}, 1.72 \mathrm{mmol})$, and the mixture was stirred for $2 \mathrm{hr}$ under reflux at $100^{\circ} \mathrm{C}$ under argon. After cooling, the mixture was diluted with chloroform. The chloroform solution was washed with saturated hydrogen sulfide solution, and the black precipitate of mercuric sulfide was filtered off over Celite. The filtrate was washed with saturated sodium hydrogen carbonate solution and brine, dried with sodium sulfate, and concentrated in vacuo. The residue was chromatographed over silica gel $(50 \mathrm{~g})$. Elution with chloroform-ethyl acetate (49:1) gave crude 18, which was recrystallized from nhexane to give $881 \mathrm{mg}(90 \%)$ of $\mathbf{1 8}$ as rods, mp $72.0 \sim 72.5^{\circ} \mathrm{C} ;[\alpha]_{\mathrm{D}}^{27}-2.96^{\circ}\left(c=0.38, \mathrm{CHCl}_{3}\right) ;$ IR $v_{\max }$ $\mathrm{cm}^{-1} 3450$ (s), 3300 (s), 1760 (vs), 1645 (s), 1550 (s), 1470 (s), 1370 (s), 1280 1210 (vs, br.), 1080 (s), 1060 (s), 960 $(\mathrm{m}), 720(\mathrm{~m}) ; \mathrm{NMR} \delta_{\mathrm{H}}\left(100 \mathrm{MHz}, \mathrm{CDCl}_{3}\right) 0.88(6 \mathrm{H}, \mathrm{t}, J=$ $6.0 \mathrm{~Hz}), 1.27(48 \mathrm{H}$, br. s), $2.00 \sim 2.35(6 \mathrm{H}, \mathrm{m}), 2.00(3 \mathrm{H}, \mathrm{s})$, $2.06(6 \mathrm{H}, \mathrm{s}), 2.16(3 \mathrm{H}, \mathrm{s}), 3.54(1 \mathrm{H}, \mathrm{dd}, J=4.5,9.5 \mathrm{~Hz})$, $3.68 \sim 4.00(2 \mathrm{H}, \mathrm{m}), 4.01 \sim 4.25(3 \mathrm{H}, \mathrm{m}), 4.44(1 \mathrm{H}, \mathrm{d}, J=$ $7.0 \mathrm{~Hz}), 5.01(1 \mathrm{H}, \mathrm{dd}, J=3.5,10.0 \mathrm{~Hz}), 5.08 \sim 5.66(5 \mathrm{H}$, m). Anal. Found: C, 67.25; H, 10.11; N, 1.61. Calcd. for $\mathrm{C}_{48} \mathrm{H}_{85} \mathrm{O}_{11} \mathrm{~N}: \mathrm{C}, 67.65 ; \mathrm{H}, 10.05 ; \mathrm{N}, 1.64 \%$.

$\left(2^{\prime} R, 4^{\prime} E\right)-1-O-\left(2^{\prime}-\right.$ Hexadecanoylamino-4'-octadecenyl $)-$ $\beta$-D-galactopyranoside (3). Sodium methoxide in methanol $(28 \%, 0.20 \mathrm{ml}, 0.98 \mathrm{mmol})$ was added to a solution of $\mathbf{1 8}$ (400 $\mathrm{mg}, 0.496 \mathrm{mmol})$ in methanol-tetrahydrofuran $(4: 3$, $35 \mathrm{ml}$ ). The mixture was stirred for $1.5 \mathrm{hr}$ at room temperature. It was then neutralized by addition of ion-exchange resin (Amberlyst-15, 2.50g, $1.00 \mathrm{mmol}$ ) and stirred for $30 \mathrm{~min}$ at room temperature. After filtration through Celite, the filtrate was concentrated in vacuo. The residue was chromatographed over silica gel $(40 \mathrm{~g})$. Elution with chloroform-methanol $(9: 1)$ gave $285 \mathrm{mg}(89 \%)$ of 3 as white granules, $\mathrm{mp} 144 \sim 146^{\circ} \mathrm{C} ;[\alpha]_{\mathrm{D}}^{23}-11.7^{\circ}(c=0.20$, $\mathrm{CH}_{3} \mathrm{OH}$ ); IR $v_{\max } \mathrm{cm}^{-1} 3400$ (s), 3300 (vs), 2960 (s), 2930 (vs), 2860 (vs), 1650 (vs), 1555 (s), 1470 (s), 1440 (w), 1420 $(\mathrm{w}), 1370(\mathrm{~m}), 1120(\mathrm{~m}), 1075(\mathrm{vs}), 1160(\mathrm{~s}), 1150(\mathrm{~s}), 1020$ (m), $980(\mathrm{~m}), 960(\mathrm{~m}), 860(\mathrm{w}), 785(\mathrm{~m}), 715(\mathrm{~s})$; NMR $\delta_{\mathrm{H}}$ 
$\left(400 \mathrm{MHz}, \mathrm{C}_{5} \mathrm{D}_{5} \mathrm{~N}\right) 0.877\left(6 \mathrm{H}, t, J=7.0 \mathrm{~Hz}, 18^{\prime}-\mathrm{H}_{3}, 16^{\prime \prime}-\right.$ $\left.\mathrm{H}_{3}\right), 1.27(44 \mathrm{H}$, br. $), 1.35(2 \mathrm{H}, \mathrm{m}), 1.73 \sim 1.89\left(2 \mathrm{H}, \mathrm{m}, 3^{\prime \prime}-\right.$ $\left.\mathrm{H}_{2}\right), 1.996\left(2 \mathrm{H}, \mathrm{q}\right.$-like, $\left.J=5.5 \mathrm{~Hz}, 6^{\prime}-\mathrm{H}_{2}\right), 2.377(2 \mathrm{H}, \mathrm{t}, J=$ $\left.7.5 \mathrm{~Hz}, 2^{\prime \prime}-\mathrm{H}_{2}\right), 2.451\left(1 \mathrm{H}\right.$, ddd, $J=6.0,7.8,13.0 \mathrm{~Hz}, 3^{\prime}-$ $\mathrm{H}), 2.586\left(1 \mathrm{H}, \mathrm{dt}, J=13.0,5.5 \mathrm{~Hz}, 3^{\prime}-\mathrm{H}\right), 3.904(1 \mathrm{H}, \mathrm{dd}$, $\left.J=5.5,10.0 \mathrm{~Hz}, 1^{\prime}-\mathrm{H}\right), 4.060(1 \mathrm{H}, \mathrm{t}-$ like, $J=6.0 \mathrm{~Hz}, 2-\mathrm{H})$, $4.148(1 \mathrm{H}, \mathrm{dd}, J=3.5,9.5 \mathrm{~Hz}, 6-\mathrm{H}), 4.316(1 \mathrm{H}, \mathrm{dd}, J=5.0$, $\left.10.0 \mathrm{~Hz}, 1^{\prime}-\mathrm{H}\right), 4.40 \sim 4.48(2 \mathrm{H}, \mathrm{m}, 3-\mathrm{H}, 5-\mathrm{H}), 4.477(1 \mathrm{H}$, dd, $J=7.8,9.5 \mathrm{~Hz}, 6-\mathrm{H}), 4.564(1 \mathrm{H}$, d-like, $J=3.0 \mathrm{~Hz}, 4-$ H), $4.621\left(1 \mathrm{H}, \mathrm{m}, 2^{\prime}-\mathrm{H}\right), 4.828(1 \mathrm{H}, \mathrm{d}, J=7.8 \mathrm{~Hz}, \mathrm{I}-\mathrm{H})$, $5.540\left(1 \mathrm{H}, \mathrm{dt}, J=15.0,5.5 \mathrm{~Hz}, 5^{\prime}-\mathrm{H}\right), 5.587(1 \mathrm{H}, \mathrm{dt}$, $\left.J=15.0,5.5 \mathrm{~Hz}, 4^{\prime}-\mathrm{H}\right), 6.27(4 \mathrm{H}$, br., $\mathrm{OH}), 8.200(1 \mathrm{H}, \mathrm{d}$, $J=8.8 \mathrm{~Hz}, \mathrm{NH}) ; \delta_{\mathrm{C}}\left(100 \mathrm{MHz}, \mathrm{C}_{5} \mathrm{D}_{5} \mathrm{~N}\right) 14.28(\mathrm{q}), 22.95(\mathrm{t})$, $26.41(\mathrm{t}), 29.58(\mathrm{t}), 29.62(\mathrm{t}), 29.77(\mathrm{t}), 29.84(\mathrm{t}), 30.00(\mathrm{t})$, $32.15(\mathrm{t}), 33.00(\mathrm{t}), 35.48(\mathrm{t}), 36.91(\mathrm{t}), 50.01(\mathrm{~d}), 62.40(\mathrm{t})$, 70.24 (d), 72.46 (t), 72.75 (d), 75.41 (d), 77.07 (d), 106.35 (d), 126.89 (d), 133.47 (d), 173.02 (s), multiplicities were determined by an INEPT experiment; FD-MS $m / z$ : 684 $(\mathrm{M}+\mathrm{H})^{+}, 706(\mathrm{M}+\mathrm{Na})^{+}$. Anal. Found: C, 70.23; H, 11.11; $\mathrm{N}, 2.07$. Caled. for $\mathrm{C}_{40} \mathrm{H}_{77} \mathrm{O}_{7} \mathrm{~N}: \mathrm{C}, 70.23 ; \mathrm{H}, 11.35$; $\mathrm{N}, 2.05 \%$.

$\left(2^{\prime} R, 4^{\prime} E\right)-1-O-\left(2^{\prime}-\right.$ Hexadecanoylamino-4'-octadecenyl $)-$ 2,3,4,6-tetra-O-acetyl- $\beta$-D-glucopyranoside (19). In the same manner as that described for the synthesis of 18,2 $(300 \mathrm{mg}, 0.575 \mathrm{mmol}$ ) and tetra- $O$-acetylglucopyranosyl bromide ( $355 \mathrm{mg}, 0.860 \mathrm{mmol}$ ) gave $373 \mathrm{mg}(76 \%$ ) of 19 as rods, $\operatorname{mp} 91.0 \sim 91.5^{\circ} \mathrm{C} ;[\alpha]_{D}^{17}+5.60^{\circ}\left(c=0.44, \mathrm{CHCl}_{3}\right) ; \mathrm{IR}$ $v_{\max } \mathrm{cm}^{-1} 3450(\mathrm{~s}), 3340(\mathrm{~s}), 1750(\mathrm{vs}), 1645(\mathrm{~s}), 1550(\mathrm{~s})$, 1470 (s), 1380 (s), 1365 (s), $1280 \sim 1210$ (vs, br.), 1100 (s), $1055(\mathrm{~s}), 965(\mathrm{~m}), 720(\mathrm{~m})$; NMR $\delta_{\mathrm{H}}\left(100 \mathrm{MHz}, \mathrm{CDCl}_{3}\right)$ $0.88(6 \mathrm{H}, \mathrm{t}, J=6.0 \mathrm{~Hz}), 1.27(48 \mathrm{H}$, br. s $), 2.01(3 \mathrm{H}, \mathrm{s}), 2.04$ $(3 \mathrm{H}, \mathrm{s}), 2.06(3 \mathrm{H}, \mathrm{s}), 2.10(3 \mathrm{H}, \mathrm{s}), 1.85 \sim 2.35(6 \mathrm{H}, \mathrm{m})$, $3.45 \sim 4.54(9 \mathrm{H}, \mathrm{m}), 4.85 \sim 5.66(3 \mathrm{H}, \mathrm{m})$. Anal. Found: $\mathrm{C}$, 67.26; $\mathrm{H}, 10.05 ; \mathrm{N}, 1.67$. Calcd. for $\mathrm{C}_{48} \mathrm{H}_{85} \mathrm{O}_{11} \mathrm{~N}: \mathrm{C}, 67.65$; $\mathrm{H}, 10.05 ; \mathrm{N}, 1.64 \%$.

$\left(2^{\prime} R, 4^{\prime} S\right)-1-O-\left(2^{\prime}\right.$-Hexadecanoylamino-4'-octadecenyl $)-$ $\beta$-D-glucopyranoside (4). In the same manner as that described for the synthesis of $\mathbf{3}, 19(195 \mathrm{mg}, 0.230 \mathrm{mmol})$ gave $140 \mathrm{mg}(89 \%)$ of 4 as white granules, $\mathrm{mp} 125 \sim 127^{\circ} \mathrm{C}$; $[\alpha]_{\mathrm{D}}^{23}-23.1^{\circ}\left(c=0.25, \mathrm{CH}_{3} \mathrm{OH}\right)$; IR $v_{\max } \mathrm{cm}^{-1} 3450(\mathrm{~s})$, 3350 (s), 2960 (s), 2930 (vs), 2860 (vs), 1625 (s), 1550 (s), $1470(\mathrm{~s}), 1435(\mathrm{~m}), 1370(\mathrm{~m}), 1160(\mathrm{~m}), 1110(\mathrm{~s}), 1080(\mathrm{~s})$, $1035(\mathrm{~s}), 965(\mathrm{~m}), 720(\mathrm{~m}) ; \mathrm{NMR} \delta_{\mathrm{H}}\left(400 \mathrm{MHz}, \mathrm{C}_{5} \mathrm{D}_{5} \mathrm{~N}\right)$ $0.875\left(6 \mathrm{H}, \mathrm{t}, J=7.0 \mathrm{~Hz}, 18^{\prime}-\mathrm{H}_{3}, 16^{\prime \prime}-\mathrm{H}_{3}\right), 1.27(44 \mathrm{H}, \mathrm{br}$.), $1.35(2 \mathrm{H}, \mathrm{m}), 1.73 \sim 1.89\left(2 \mathrm{H}, \mathrm{m}, 3^{\prime \prime}-\mathrm{H}_{2}\right), 2.000(2 \mathrm{H}$, qlike, $\left.J=6.0 \mathrm{~Hz}, 6^{\prime}-\mathrm{H}_{2}\right), 2.395\left(2 \mathrm{H}, \mathrm{t}, J=7.5 \mathrm{~Hz}, 2 \mathrm{H}, 2^{\prime \prime}\right.$. $\left.\mathrm{H}_{2}\right), 2.468\left(1 \mathrm{H}, \mathrm{ddd}, J=6.0,8.2,13.0 \mathrm{~Hz}, 3^{\prime}-\mathrm{H}\right), 2.615(1 \mathrm{H}$, $\left.\mathrm{dt}, J=13.0,5.5 \mathrm{~Hz}, 3^{\prime}-\mathrm{H}\right), 3.901(1 \mathrm{H}, \mathrm{dd}, J=5.5,10.2 \mathrm{~Hz}$, $\left.\mathrm{l}^{\prime}-\mathrm{H}\right), 3.92 \sim 3.98(1 \mathrm{H}, \mathrm{m}, 5-\mathrm{H}), 4.053(1 \mathrm{H}, \mathrm{t}-\mathrm{like}, J=$ $9.0 \mathrm{~Hz}, 2-\mathrm{H}), 4.19 \sim 4.26(2 \mathrm{H}, \mathrm{m}, 3-\mathrm{H}, 4-\mathrm{H}), 4.310(1 \mathrm{H}, \mathrm{dd}$, $\left.J=5.2,10.2 \mathrm{~Hz}, 1^{\prime}-\mathrm{H}\right), 4.384(1 \mathrm{H}, \mathrm{dd}, J=5.5,12.0 \mathrm{~Hz}, 6$ $\mathrm{H}), 4.544(1 \mathrm{H}, \mathrm{dd}, J=2.4,12.0 \mathrm{~Hz}, 6-\mathrm{H}), 4.61 \sim 4.70(1 \mathrm{H}$, $\left.\mathrm{m}, 2^{\prime}-\mathrm{H}\right), 4.916(1 \mathrm{H}, \mathrm{d}, J=7.8 \mathrm{~Hz}, 1-\mathrm{H}), 5.556(1 \mathrm{H}, \mathrm{dt}, J=$ $\left.15.0,5.5 \mathrm{~Hz}, 5^{\prime}-\mathrm{H}\right), 5.606\left(1 \mathrm{H}, \mathrm{dt}, J=15.0,5.5 \mathrm{~Hz}, 4^{\prime}-\mathrm{H}\right)$, $6.05(4 \mathrm{H}$, br., $4 \mathrm{OH}), 8.269(1 \mathrm{H}, \mathrm{d}, J=8.8 \mathrm{~Hz}, \mathrm{NH}) ; \delta_{\mathrm{C}}$ $\left(100 \mathrm{MHz}, \mathrm{C}_{5} \mathrm{D}_{5} \mathrm{~N}\right) 14.28(\mathrm{q}), 22.94(\mathrm{t}), 26.43(\mathrm{t}), 29.62(\mathrm{t})$, $30.00(\mathrm{t}), 32.15(\mathrm{t}), 33.00(\mathrm{t}), 35.49(\mathrm{t}), 36.91(\mathrm{t}), 50.01(\mathrm{~d})$, $62.87(\mathrm{t}), 71.62(\mathrm{~d}), 72.61(\mathrm{t}), 75.32(\mathrm{~d}), 78.59(\mathrm{~d}), 105.83$ (d), $122.23(\mathrm{t}), 122.41$ (t), 126.86 (d), 133.50 (d), 173.07 (s), multiplicities were determined by an INEPT experiment; FD-MS $m / z: 684(\mathrm{M}+\mathrm{H})^{+}, 706(\mathrm{M}+\mathrm{Na})^{+}$. Anal. Found: C, 70.01; H, 11.21; N, 2.11. Calcd. for $\mathrm{C}_{40} \mathrm{H}_{77} \mathrm{O}_{7} \mathrm{~N}$ : C, $70.23 ; \mathrm{H}, 11.35 ; \mathrm{N}, 2.05 \%$

Acknowledgments. We thank Professor Y. Nagai for his suggestion to undertake this work, which was supported by a Grant-in-Aid for Scientific Research from the Ministry of Education, Science and Culture of Japan.

\section{References}

1) 2-Aminotetradeca-5,7-dien-3-ol, bearing a resemblance to sphingosines, was isolated from the sponge Xestospongia sp. as a growth inhibitor of Candida albicans. See N. K. Gulavita and P. J. Scheuer, J. Org. Chem, 54, 366 (1989).

2) A. P. Krapcho and A. J. Lovey, Tetrahedron Lett., 12, 957 (1973).

3) Y. Masaoka, M. Sakakibara and K. Mori, Agric. Biol. Chem., 46, 2319 (1982).

4) J. R. Rachele, J. Org. Chem., 28, 2898 (1963)

5) K. Soai and A. Ookawa, J. Org. Chem., 51, 4000 (1986).

6) N. Yamaoka, K. Aso and K. Matsuda, J. Org. Chem., 30, 149 (1965) 